\title{
Tourism and World Heritage in the Central Eastern Rainforest Reserve, Australia
}

Buckley, R., Ward, J., and Warnken, W.

CRC Tourism and International Centre for Ecotourism Research, Griffith University, Parklands Drive, Southport, Queensland, 4217 Australia;

Phone: 61-7-55948675, Fax: 61-7-55948895, Email: r.buckley@mailbox.gu.edu.au,

The Central Eastern Rainforest Reserve Australia (CERRA) World Heritage Area comprises 8 groups of forest reserves scattered between Lamington National Park in southeast Queensland and Barrington Tops in central New South Wales. Most of the areas between these reserves have either been cleared for farming, or are State forests subject to logging. These forest reserves form a remnant of a once-continuous forest cover throughout the area. The future tenure and use of areas outside the reserves, many of which are equally valuable in terms of their natural heritage, is currently under debate as part of the so-called Comprehensive Regional Assessment process for Australian's forests nationally. This process grew from sharp controversy between the logging industry and conservation groups over the use of remaining forest areas. During this process, it has become very clear that conservation and logging are not the only two relevant land uses. Tourism is a third and at least equally important sector, and one which is continuing to grow in economic scale, geographic extent, and political visibility. This has been reflected in the recently-concluded South-East Queensland Forests Agreement (Keto and Scott 1999: 1, Schneiders 1999: 1).

\section{Tourism in National Parks}

In national park areas, tourism has been recognised as a major land use requiring active management planning and resources at both State and local scales (Worboys 1998, QPWS 1999). The parks provide a tourist attraction which generates tourism revenue in gateway 
towns, many of which are in rural regions which are otherwise economically depressed (Tourism Queensland 1996). At the same time, the growth of tourism and recreation in the parks is consuming an ever-larger portion of the remarkably small management budgets available, so that park staff have less and less time and resources available to manage other threats to conservation values, such as weeds and feral animals. In addition, tourism itself is becoming a significant local threat to conservation values in some areas. Planning for conservation and tourism jointly is becoming increasingly urgent and important both for the parks and the tourism industry. Additional funds for monitoring and management of parks and visitors could be provided either by a direct levy on tourism, or preferably through considerably increased government funding to parks agencies in recognition of their key role in underpinning the regional tourism industry.

\section{Tourism in Public Forests}

As the same time, commercial tourism and private recreation are growing rapidly in State forest areas, partly in response to increased crowding and regulation in adjacent national parks. The economic significance of tourism in these forests needs to receive greater recognition. In the Wet Tropics of Queensland World Heritage Area further north, the changeover from logging to tourism yielded a seven-fold increase in revenue (Driml and Common 1995), and a similar result is likely if the central eastern rainforests made the same change (Ward 1999). The increase in tourism in State forests has received some political recognition to date, with the transfer of some State forest areas in northern NSW to the national parks estate. Whether additional funding will be adequate for management of these increased areas remains to be seen. It may also require an explicit zoning approach, where different types of tourist activity, with different equipment and impacts, are permitted in essentially similar environments, simply as a reflection of their different land-use histories. An alternative approach, and one with potentially much wider ramifications, would be for forestry agencies to embrace the tourism industry as an equal part of 
their political constituencies and user group, along with the logging industry; to retain tenure over the land concerned, but to plan explicitly for a growing tourism industry, in concert with a changing timber industry. These considerations apply equally to many other areas in Australia and indeed internationally.

\section{Economic Value of Tourism in CERRA Parks}

The tourism value of the national park estate in Queensland has recently been estimated at approximately $\$ 1$ billion annually (Kinhill Economics 1998), and that of Victoria at $\$ 340$ million (Read Sturgess and Associates 1999). There are also past studies of individual national parks in NSW, such as Dorrigo (Bennett 1995). The most detailed economic study to date, however, is a comparison of revenues from tourism and logging respective in 11 paired sets of National Parks and State forests throughout eastern Australia (Ward 1999). Logging revenues were determined from forestry sales statistics, and tourism values from travel-cost calculations, based on large-scale on-ground surveys supplemented with regional visitor data from national tourism statistics. This study, due for completion in 2000, has shown that the economic value of forested lands in central eastern Australia is at least an order of magnitude greater for tourism than it is for logging; in line with results from the Wet Tropics. It has also shown that World Heritage designation, by greatly increasing the international visibility of an area, greatly increases visitation rates and hence current economic value as calculated by travel-cost approaches. The study has made particular attempts to overcome the limitations of past travelcost analysis, eg in relation to the value-adding chain in different industry sectors, and in relation to the economic value of travel time. It has considered only direct use values and has avoided the use of regional economic multipliers, so its estimates of tourism value are very conservative. It has also included the costs of transporting timber to mills as a component of its value, in addition to royalties, so its estimates of logging blues are very liberal. 


\section{Environmental Impacts of Tourism in CERRA Parks}

Different tourism activities have different types of environmental impacts, and the significance of particular impacts differs between ecosystems. Trampling of vegetation, a heavily studied impact of tourism in northern hemisphere national parks, is of little ecological significance in the sub-tropical rainforest and wet and dry eucalypt forests of eastern Australia, except in the montane snowgum forests of the Australian Alps, and the montane southern beech forests of Tasmania and the Qld/NSW border. Potentially much more significant impacts are the introduction of weeds and pathogens, noise disturbance to rare fauna, and contamination of otherwise pristine watercourses. Noise impacts are easily observable but hard to quantify in population terms; weed invasion is widespread and readily apparent, but dispersal mechanisms and management measures are little-known. Plant pathogens such as cinnamon fungus, Phytophthora cinnamoni, is a major threat to plant conservation in Western Australia, Tasmania and part of Victoria, and its significance is under study in NSW and Qld. Tourists are a significant factor in its dispersal in national parks, though logging vehicles are likely to be far more significant in State forests. Water quality is a particularly important indicator of visitor impacts in national parks, as to some extent it integrates impacts throughout the catchment. It is also significant because water quality impacts are not immediately apparent to the naked eye; because many of the endemic species in the forest areas are aquatic; and because visitors like to drink and swim in the creeks, so water quality is significant for human as well as ecosystem health.

The most detailed water quality study to date analysed over 3,600 samples from heavily-visited swimming holes and little-visited control sites in the main rivers of Lamington National Park in southeast Queensland, in many ways the archetype of the Central Eastern Rainforest World Heritage Area. This study found significant increases in concentrations of the mammalian gut bacteria Escherichia coli from upstream to downstream at swimming holes, but not at control 
sites; indicating that even relatively low-level recreational activities can have detectable environmental impacts in otherwise pristine national park areas (Warnken 1998). Even more significant from a human health perspective, a subsequent study has shown that the pathogenic human protozoa Giardia and Cryptosporidium, which were believed to be present only in agricultural areas in Australia, are in fact widespread in pristine watercourses in rainforest reserves in eastern Australia (Warnken \& Buckley, in rev.). Pathogenic bacteria such as Plesiomonas shigelloides have also been detected in these water courses (Buckley et al 1998: 253).

\section{Tourism Trends in CERRA}

In summary, the following trends are occurring in the Central Eastern Rainforest Reserve World Heritage Area. Tourism is increasing rapidly, both in total numbers, geographic extent, and the intensity of backcountry use. The economic value of National Parks for tourism is being recognised and quantified, though this is not yet reflected in parks management budgets. The role of tourism in State forests is also being recognised, and the interaction between recreational and timber-production uses of State forests, as well as the conservation estate, is currently the subject of intense political debate in Australia. The significance of World Heritage designation as a tourist drawcard is being recognised by tourism entrepreneurs. For example, there is a successful tourist cablecar in the Qld Wet Tropics WHA, and a proposed copy in a sector of the CERRA WHA, near the major tourist centres of southeast Qld. The environmental impacts of increasing tourism in national parks are only beginning to be quantified, with many studies to date involving eyeball assessment rather than scientific measurement, and hence tending to miss the more cryptic impacts which often have the greatest ecological significance (Buckley 1999: 207). 


\section{Conclusions}

There is an urgent need for recognition of tourism and recreation as a major existing land use in the World Heritage and other forests of eastern Australia; active monitoring and management visitors and natural resources, with adequate funding, to minimise conservation impacts whilst still allowing growth in tourism revenue; and encouragement for the growth of tourism in state forests and other public lands, so that national parks can be retained for conservation and minimal-impact recreation. The economic and environmental arguments for all of the above are straightforward and cogent; but the political realities are likely to be quite the opposite.

\section{REFERENCES}

BENNETT, JOHN 1995. Economic Value of Recreational Use: Gibraltar Range and Dorrigo National Parks. NSWNPWS Environmental Economics Series. NSW Government Printer, Sydney.

BUCKLEY, RALF 1999. Tools and indicators for managing tourism in parks. Annals of Tourism Research 26: 207-210.

BUCKLEY, RALF 1999. Tourism and Biodiversity: Land-use, Planning and Impact Assessment. Earth Alive Conference.

BUCKLEY, RALF, ELIZABETH CLOUGH and WIEBKE WARNKEN 1998. Plesiomonas shigelloides in Australia. Ambio 27: 253.

DRIML, SALLY and MICK COMMON 1995 Economic and financial benefits of tourism in major protected areas. Australian Journal of Environmental Management, 2: 19-29. 
KETO, AILA and KEITH SCOTT 1999. SEQ Forests Agreement brings peace. Rainforest News 32: 1-4.

KINHILL ECONOMICS 1998. The Value of Protected Areas to Queensland. Kinhill Economics, Brisbane.

QUEENSLAND PARKS AND WILDLIFE SERVICES 1999. Draft Plan of Management Lamington National Park. QPWS, Brisbane.

READ STURGESS \& ASSOCIATES, 1999. Economic Assessment of Recreation Values of Victorian Parks. RSA, Melbourne.

SCHNEIDERS, LYNDON 1999. Forests of South East Queensland have been protected. Wilderness News, October 1999, 1-4. The Wilderness Society, Brisbane.

TOURISM QUEENSLAND 1997. Queensland Ecotourism Plan. Department of Tourism, Small Business and Industry, Brisbane.

WARD, JOHN 1999. The Relative Net Economic Benefits of Logging And Tourism in Native Australian Forests. PhD Thesis, Griffith University, Gold Coast Australia.

WARNKEN, WIEBKE 1998. Threshold Detection of Ecotourism Impact: Microbiological and chemical indicators of recreational effects on eater quality in a subtropical rainforest conservation reserve. PhD Thesis, Griffith University, Gold Coast Australia. 
WARNKEN, WIEBKE and RALF BUCKLEY (in review). Giardia and Cryptosporidium in pristine Australian watercources. Journal of Applied Environmental Microbiology.

WORBOYS, GRAEME 1997. Draft Nature Tourism and Recreation Strategy. NSW National Parks and Wildlife Service, Sydney. 